DOI: $10.15290 /$ bsl.2016.08.12

\author{
Agnieszka Izdebska \\ Katedra Teorii Literatury \\ Uniwersytet Łódzki \\ e-mail: agniz@poczta.onet.pl
}

\title{
Kilka uwag o konstrukcji przestrzeni w prozie W.G. Sebalda
}

Pisanie - czy w ogóle wypowiadanie się - o twórczości W.G. Sebalda ${ }^{1}$ obciążone jest wieloma niebezpieczeństwami. Agata Sierbińska, w tekście W.G. Sebald. Zrujnowana pamięć, zamieszczonym w poświęconym pisarzowi numerze „Kontekstów”, tak określiła podstawowy w tym wypadku kłopot:

o twórczości Sebalda napisano «zbyt wiele», co stawia nas, badaczki i badaczy, w trudnym położeniu - każe szukać nieopisanych jeszcze fragmentów, wątpliwości, które nie zostały dotąd rozwiązane, i zastanawiać się - czy rzeczywiście zostało coś jeszcze do powiedzenia? ${ }^{2}$

1 Pisarz konsekwentnie posługiwał się tylko inicjałami dwojga swoich imion: Wienfried Georg, uważając ich pełne brzmienie za nadto Heglowsko-germańskie. Zob. A. Zagajewski, Melancholijny i konkretny, "Zeszyty Literackie” 2012, nr 2, s. 35.

2 A. Sierbińska, W.G. Sebald. Zrujnowana pamięć, „Konteksty” 2014, nr 3-4, s. 93. Bibliografia tekstów poświęconych twórczości Sebalda jest tak obszerna, że zamieszczenie tu nawet jej niepełnego wyboru byłoby zabiegiem nieco jałowym. Mark M. Anderson odnotowuje, że ten wysyp tekstów naukowych poświęconych pisarzowi miał miejsce po jego tragicznej i przedwczesnej śmierci. Wcześniej twórczość Sebalda była komentowana i recenzowana niemal wyłącznie w czasopismach. Anderson konstatuje nieco asekuracyjnie, że obszerność literatury odnoszącej się do Sebalda wyklucza możliwość choćby pobieżnego zrelacjonowania głównych pojawiających się w niej wątków [M.M. Anderson, Documents, Photography, Postmemory: Alexander Kluge, W.G. Sebald, and the German Family, „Poetics Today” 2008, vol. 29, nr 1, Spring, s. 139]. 
Powołuję się na tę wypowiedź, ponieważ - jak zapewne wszyscy o Sebaldzie, mimo wszystko, piszący - mając świadomość owego nadmiaru (czy może relatywnego nadmiaru) nie mogę pozbyć się poczucia, że jego pisarstwo mimo wszystko ciągle wymyka się domknięciom, pozostaje nie-do-opisane, nie-do-zanalizowane. A ranga tekstów Sebalda nie pozostawia wątpliwości: mamy do czynienia $\mathrm{z}$ jednym $\mathrm{z}$ najciekawszych dwudziestowiecznych twórców, a i ze zjawiskiem istotnym dla przemiany formy powieściowej w ostatnich dekadach XX wieku.

Jednym z powodów, dla których tak wielu piszących o Sebaldzie czuje się sprowokowanych do kolejnych dopowiedzeń jest hybrydyczność jego dzieł³. Realizuje się ona na wielu poziomach: językowym, tekstowym, świata przedstawionego, konwencji gatunkowych i narracyjnych. W swoistej autoprezentacji on sam konstatował zresztą: „pracuję według systemu bricolage w sensie Levi-Straussa" ${ }^{4}$. Przywołana już tu Sierbinska odnotowując ów nadmiar tekstów poświęconych pisarzowi stwierdza też, że ta nadprodukcja sprowokowana jest zapewne również przez rozległość jego lektur:

czytając Sebalda dostatecznie dokładnie, nie da się nie zauważyć, że niemal wszystkie podręczne narzędzia interpretacyjne, teorie i kategorie, które dobrze przystają do jego twórczości, zostały przezeń zaprojektowane, czy nawet (z)użyte - przekształcone w literaturę ${ }^{5}$.

Pietro Citati pisząc o specyfice pisarstwa Sebalda stwierdza:

Podczas gdy wiele współczesnych powieści zamierza jedynie opowiadać, Sebald przypomina nam, że powieść jest przede wszystkim systemem: opowiadaniem, traktatem $z$ dziedziny architektury, botaniki, ornitologii, wiedzy o twierdzach, namysłem nad cierpieniem i czasem. Aby pozostać wiernym prawdziwemu powołaniu powieści, Sebald opowiada o całym świecie, kataloguje go, odbija, systematyzuje, konstruuje ${ }^{6}$.

Jeśli uznać tę rekonstrukcję projektu wpisanego w twórczość Sebalda za fortunną, to mamy tu do czynienia $z$ zamierzeniem totalnym na tyle, na ile to możliwe u schyłku wieku XX - pisarz bowiem zdaje się doskonale świadomy nieuchronnych ograniczeń opowiadania, katalogowania, odbija-

\footnotetext{
3 Zob. na przykład Lynn L. Wolff, W.G. Sebald Hybrid Poetics: Literature as Historiography, Berlin, 2014.

4 W.G. Sebald, Wyimki, wybór i przeł. M. Łukasiewicz, "Zeszyty Literackie” 2012, nr 2, s. 41.

5 A. Sierbińska, W.G. Sebald. Zrujnowana pamięć, s. 93.

6 P. Citati, Arcydzieło Sebalda, przeł. J. Ugniewska, „Zeszyty Literackie” 2012, nr 2, s. 118.
} 
nia, systematyzowania, konstruowania. Stąd jego postawa bricolera i przymus badaczy tyleż śledzących to, co opowiedziane, skatalogowane itd., co ujawniających to, co w tekstach Sebalda tkwi jako nieobecne czy ewokowane zaledwie.

Bez wątpienia istotnym aspektem strategii pisarza, o zasadniczym znaczeniu i rozlicznych konsekwencjach dla poruszanego tu zagadnienia, jest włączanie przez Sebalda w tekst werbalny znaków ikonicznych - fotografii. Są to zdjęcia pejzaży, ludzi, drobnych przedmiotów, zwierząt, wycinków prasowych, fragmentów zapisków bohaterów ${ }^{7}$. Ten element, budujący hybrydyczność jego tekstów, wpływa znacząco na rozmaite aspekty pojawiania się $\mathrm{w}$ nich przestrzeni.

Sam pisarz wielokrotnie wypowiadał się na temat roli zdjęć we własnych utworach - w jednym $\mathrm{z}$ wywiadów opisał ich funkcję następująco:

Pierwsza i oczywista to uwiarygodnienie - wszyscy mamy tendencję wierzyć bardziej obrazom niż słowom [...] fotografie pozwalają narratorowi uwiarygodnić historię, którą opowiada. Myślę, że to zawsze był problem realistycznej fikcji [...]. W dziewiętnastym wieku [...] autor zawsze musiał się natrudzić, [...] aby nadać całej opowiadanej przez siebie historii znamiona autentyczności. Druga funkcja fotografii [...] to zatrzymanie czasu. Fikcja to forma sztuki, która płynie w czasie, która nieubłaganie zmierza do końca [...]. Bardzo, bardzo trudno w konkretnej formie narracyjnej zatrzymać upływ czasu. A to, jak wszyscy wiemy, jest tym, co lubimy tak bardzo w pewnych formach sztuki wizualnej [...]. Zostajesz wyjęty z czasu i jest to w pewnym sensie forma wybawienia [...]. Fotografie także mogą to sprawić - działają jak bariery lub tamy, które hamują nurt. Myślę, że to jest pozytywne, takie spowolnienie prędkości czytania ${ }^{8}$.

W przytoczonej powyżej wypowiedzi Sebald eksponuje rolę zdjęć jako elementu uwiarygodnienia przywoływanych opowieści. Ów referencjalny czy indeksalny aspekt fotografii $\mathrm{w}$ tekstach pisarza jest przedmiotem dyskusji we wszystkich niemal artykułach poświęconych jego twórczości, zatem nieuchronnie kwestia ta jeszcze się tu pojawi.

\footnotetext{
7 S. Harskotte podkreśla, że układ fotografii był przez pisarza bardzo precyzyjnie zaplanowany: „The typescripts which Sebald submitted to his publishers (now in the collection of the German Literature Archive, Marbach) show that he carefully planned the location of his photographic inserts" [S. Harskotte, Photo-Text Topographies: Photography and the Representation of Space in W. G. Sebald and Monika Maron, „Poetics Today” 2008, vol. 29, nr 1, Spring, s. 58]. Ten element $\mathrm{w}$ twórczości pisarza, wraz $\mathrm{z}$ włączaniem do tekstów nietłumaczonych zwrotów obcojęzycznych, stwarza oczywiście rozliczne problemy translatorskie [s. 55]. Autorka nazywa książki Sebalda foto-tekstami powstałymi na zasadzie podobnej do albumów z wycinkami (scrapbook) [s. 51-53].

8 E. Wachtel, Łowca duchów, przeł. M. Sadowska, „Konteksty” 2014, nr 3-4, s. 33.
} 
Jednocześnie Sebald przyznawał, że niektóre fotografie prowokowały go do snucia opowieści - tak było na przykład ze zdjęciem jego stryjecznego dziadka w stroju arabskim, w Jerozolimie ${ }^{9}$. Jeszcze bardziej złożone relacje dotyczą fotografii przez niego znalezionej, przedstawiającej dwójkę ludzi w zimowych okryciach stojących na scenie na tle nieco naiwnie wyobrażonej panoramy Alp. W tych anonimowych postaciach pisarz domyśla się impresaria z żoną albo dwójki aktorów i mówi o tym zdjęciu jako o obrazie szalenie niepokojącym, wręcz nawiedzającym go, generującym napięcie domagające się rozładowania ${ }^{10}$. Fotografia pojawi się potem w tekście powieści Austerlitz i zostanie skomentowana przez bohatera:

W pierwszej chwili wydawało jej się [mowa o Verze, dawnej opiekunce Austerlitza, odnalezionej przez niego po latach w Pradze - dop. A.I.] jak powiedziała mówił Austerlitz - że dwie postaci w lewym dolnym rogu to Agata i Maximilian [jego rodzice], przy tak małym wymiarze trudno było ich rozpoznać, ale potem zauważyła naturalnie, że to inne osoby, może impresario albo sztukmistrz i jego asystentka ${ }^{11}$.

Na pozór mogłoby się wydawać, że jednym z rezultatów takiego zabiegu, tzn. wprowadzenia w obręb tekstu werbalnego znaków ikonicznych o tak silnej referencji jak fotografie, musi być efekt mise-en-abyme - swoiste pomnożenie ewokowanych przestrzeni. Jednak porządki wprowadzane w ten sposób są, zdaniem Silke Horskotte, odległe lub nawet niewspółmierne - zestawiają przestrzeń przedstawioną na fotografii $z$ jej medialną reprezentacją, te zaś konfrontują z tekstem werbalnym i z ekstradiegetyczną przestrzenią odbioru ${ }^{12}$. Nadto $\mathrm{w}$ powieściach Sebalda kwestia referencji zdjęć jest bardzo złożona, zróżnicowana, czego efektem jest skomplikowanie ich funkcji.

Na przykład, jak twierdzi Christopher C. Gregory-Guider, w Wyjechali fotografie konkretnych obiektów i przestrzeni zamieszczone $\mathrm{w}$ tekście są częścią autorskiej strategii, którą nazywa tworzeniem biogeografii - opowiadaniem o losach ludzi poprzez pokazanie miejsc, z którymi byli

\footnotetext{
9 Tamże, s. 33.

10 C. Scholz, "But the Written word is Not a True Document: A Conversation with W.G. Sebald on Literature and Photography, w: Searching for Sebald. Photography after W.G. Sebald, ed. by L. Patt with C. Dillholmer, Los Angeles 2007, s. 109.

11 W.G. Sebald, Austerlitz, przeł. M. Łukasiewicz, Warszawa 2008, s. 224. Kolejne cytaty z powieści lokalizuję w tekście głównym, oznaczając je skrótem A.

12 S. Horskotte, Photo-Text Topographies: Photography and the Representation of Space in W. G. Sebald and Monika Maron, s. 50-51.
} 
związani ${ }^{13}$. Taką funkcję pełnią zdjęcia hoteli w opowieści, której bohaterem jest Ambros Adelwarth czy fotografie alpejskich pejzaży w historii Henry'ego Selwyna. Nieco bardziej wyrafinowany zabieg to umieszczenie w tekście rodzinnej fotografii - krewni pisarza siedzą za stołem, nad którym wisi obraz przedstawiający górską miejscowość. To Wertach im Allgäu, z którego Sebald pochodzi. Jak twierdzi Gregory-Guider, zdjęcie to stanowi swoisty komentarz, wskazujący, jak miejsca utracone rzucają swój cień zauważalny wszędzie w kreowanej przez Sebalda przestrzeni ${ }^{14}$ - tutaj w amerykańskim salonie tych, którzy Niemcy opuścili.

Zatem rację ma John Sears, który twierdzi, że w opowieściach Sebalda dominuje relacja raczej między obrazami i tekstem, nie zaś między obrazami, a tym, do czego nas odsyłają ${ }^{15}$. Zresztą we wszystkich analizach poruszających kwestię funkcji fotografii w utworach Sebalda podkreśla się, że pisarz podważa dokumentacyjny status fotografii i poddaje $\mathrm{w}$ wątpliwość ich zewnątrztekstową referencję ${ }^{16}$. Nadto, zdaniem Searsa, ta relacja (tekstu i obrazu) oparta jest na bardzo różnych zasadach, co eksponuje problematyczność relacji konwencjonalnych między fotografią i tym, co reprezentuje, a w związku $\mathrm{z}$ tym prowokuje do rozmaitych interpretacji owej relacji ${ }^{17}$. Zatem, jak twierdzi Sears, fotografie u Sebalda nie są ani ilustracją, ani kontrapunktem, ani wzmocnieniem tekstu werbalnego. Zostały użyte dla skonstruowania komplementarnej (dopełniającej) przestrzeni w obrębie tekstu, w którym „klęska” literackości jest wielokrotnie dekreto-

$13, \ldots[\ldots]$ the text contains numerous elaborate descriptions of the places through which the narrator wanders as he retraces the footsteps of his subjects. Over the course of the narrative, these photographs and descriptions of places evoke the qualities of those who once occupied and traversed them, phenomenon that qualifies The Emigrants as an autobiogeography. I use this neologism to refer to a unique subgenre of life-writing in which the story of person is refracted through the story of place, a trait that is central to a full appreciation of Sebald's memorial photography" [C. Gregory-Guider, Memorial Sights/Sites: Sebald, Photography and the Art of Autobiogeography in "The Emigrants", w: Searching for Sebald. Photography after W.G. Sebald, Los Angeles, 2007, s. 516]. Celowo nie używam tu terminu autobiogeografia, gdyż nie uważam, by Wyjechali było opowieścią Sebalda o własnej biografii wpisanej w przestrzeń.

14 „On the wall hangs painting of their (and Sebald's) place of origin, Wertach im Allgäu, a comment on the way in which the shadows of lost places are everywhere discernible in the Sebaldian landscape" [tamże, s. 527].

15 J. Sears, Photographs, Images, and the Space of Literature in Sebald's Prose, w: Searching for Sebald. Photography after W. G. Sebald, Los Angeles, 2007, s. 204.

16 Nawet M. M. Anderson (Documents, Photography, Postmemory: Alexander Kluge, W. G. Sebald, and the German Family) uznający Sebalda za pisarza tworzącego „prozę dokumentalną", uznaje, że użycie przez niego fotografii jest elementem bardzo złożonej strategii realistycznej [s. 129].

17 J. Sears, Photographs, Images, and the Space of Literature in Sebald's Prose, s. 204. 
wana ${ }^{18}$. Podobnie uważa Horskotte, twierdząc, że wobec braku zewnątrztekstowej referencji zdjęcia u Sebalda nie mają też waloru świadectwa. Nadto pojawiają się $\mathrm{w}$ tekście $\mathrm{w}$ trybie, którego motywacji nie jesteśmy $\mathrm{w}$ stanie odkryć $^{19}$. Nie da się zrekonstruować ogólnej zasady pozwalającej nam orzec, czemu w tym, a nie innym miejscu umieszczone są te czy inne zdjęcia, mimo bardzo precyzyjnego zaplanowania przez autora ich lokalizacji w tekście ${ }^{20}$. Być może zatem mamy tu do czynienia ze swoistą metatekstową tematyzacją właściwości wszystkich tekstów Sebalda, którą Carsten Strathausen opisał następująco: "Jakikolwiek rodzaj tekstualnego, geograficznego czy metafizycznego porządku wyłania się co chwila z dzieła Sebalda, zawsze jest on zagrożony i zatapia się nieuchronnie w przypadkowości i chaosie" 21 .

Komentując rozpoznania Searsa i Horskotte wyliczających, czym fotografie $\mathrm{w}$ tekstach Sebalda nie są, należałoby jednak dodać, że na osobliwy i złożony sposób bywają one ilustracją, kontrapunktem czy wzmocnieniem wobec tekstu werbalnego. Na przykład niektóre opisy miejsc czy fotografie, a nawet przypadkowe obrazy, ewokują przestrzeń nie pojawiającą się $\mathrm{w}$ obrębie świata przedstawionego, często silnie nacechowaną emocjonalnie i znaczeniowo. Jak twierdzi na przykład Sears, sekwencja zdjęć drzwi w Terezinie zamieszczona w Austerlitzu przywołuje obrazy otwartych pieców w Auschwitz $^{22}$. Na nieco podobnej zasadzie fotografia torów kolejowych w Wyjechali zamieszczona na początku części poświęconej historii Paula Bereytera nie tylko zapowiada samobójczą śmierć bohatera pod kołami pociągu. Zdaje się też pokazywać jego "niemiecką tragedię" jako wpisaną w los europejskich Żydów, przywołaną emblematycznie ${ }^{23}$ na mocy tak silnie ugruntowanego

$18, \ldots[\ldots]$ far from illustrating, counterpointing, or reinforcing the written text, images work insistently to construct complementary space within the text in which the "failure " of the literary is repeatedly enacted" [tamże, s. 206].

19 "Sebald's images are always to some extent unexpected, as are the varying ways in which each picture can be related to the narrative. In the absence of any textual reference, the photograph cannot function as either evidence or illustration" [S. Horskotte, Photo-Text Topographies: Photography and the Representation of Space in W. G. Sebald and Monika Maron, s. 58].

20 Patrz przypis 7.

21 C. Strathausen, Wędrowanie donikąd. Sebalda podróże po rozwidlających się ścieżkach, przeł. D. Czaja, "Konteksty” 2014, nr 3-4, s. 42.

22 "Each doorway rests in inscrutable silence, imposing its own illusory presence upon the reader and coming, on repeated viewing, to resemble the entrance to the ovens at Auschwitz" [J. Sears, Photographs, Images, and the Space of Literature in Sebald's Prose, w: Searching for Sebald. Photography after W. G. Sebald, s. 222].

${ }^{23}$ W kwestii związków Sebaldowskiego użycia fotografii z emblematycznością zob. S. Horskotte, Photo-Text Topographies: Photography and the Representation of Space in W.G. Sebald and Monika Maron, s. 63. 
obrazu torów kolejowych wiodących do obozu zagłady ${ }^{24}$. Podobną funkcję pełni też zdjęcie cmentarza umieszczone na początku Wyjechali - sygnalizuje jeden z głównych tematów tomu dający się zamknąć we frazie kończącej pierwszą jego część: „Tak więc umarli powracają” ${ }^{25}$. Stąd, jak zauważa Horskotte wizualne przywołanie miejsc ich spoczynku - taką też funkcję pełni fotografia lodowca, na którym zaginął Johannes Naegeli i gdzie po latach topniejący lód odsłania jego szczątki. Zatem, dodaje Horskotte, pierwsza fotografia zamieszczona $\mathrm{w}$ książce sygnalizuje symboliczną topografię całości tomu, w którym zdarzenia rozgrywają się $\mathrm{w}$ obszarze między przestrzenią żywych i tą, która należy do zmarłych. Co więcej, można też pokusić się o taką interpretację, w której sama fotografia jako medium stanowi zetknięcie się z przeszłością i tymi, których już nie ma ${ }^{26}$. Tak bowiem - jako sztukę funeralną - postrzegała fotografię choćby Susan Sontag ${ }^{27}$.

Pewne fotografie pojawiają się jako ekstrapolacje stanów wewnętrznych bohaterów lub jako ich zastępcze portrety. Tak, zdaniem Gregory-Guidera, funkcjonują zdjęcia kortu tenisowego i zaniedbanego ogrodu w Wyjechali, w części poświęconej losom Henry'ego Selwyna. Ilustrują niejako przytaczane przez narratora wypowiedzi bohatera:

Tennis used to be my great passion, rzekł dr Selwyn. But now the court has fallen into disrepair, like so much else around here. Nie tylko warzywnik, ciągnął, wskazując na wpół zrujnowane wiktoriańskie szklarnie i zarośnięte tyczki szpalerów, nie tylko warzywnik po latach zaniedbania jest $\mathrm{u}$ kresu, także pozostawiona bez dozoru natura - sam coraz wyraźniej to odczuwa - jęczy i ugina się pod brzemieniem, którym ją obarczamy [W, s. 13].

24 C. Gregory-Guider, Memorial Sights/Sites: Sebald, Photography and the Art of Autobiogeography in "The Emigrants", s. 519.

25 W.G. Sebald, Wyjechali, przeł. M. Łukasiewicz, Warszawa 2005, s. 34. Kolejne cytaty z tomu lokalizuję w tekście głównym, oznaczając je skrótem W.

26 "The photograph sets the scene for, or introduces the topography of the entire collection, much of which takes place in a shadowland between the living and the dead. [...] In The Emigrants the image introduces concepts of death, of a resting place for the dead, and of a return of the dead through (photographic) images (Harris 2001) before these themes are taken up in the ensuing verbal narrative. Moreover, by visually representing a cemetery, the photograph itself constitutes the visual space in and through which the dead are buried and forgotten. Significantly, the second episode in which the narrator talks about a burial and return of the dead-the story of Johannes Naegeli (Sebald 2002b: 14) - also uses a photograph to represent Naegeli's resting place (and the site of his unexpected reappearance)" [S. Horskotte, Photo-Text Topographies: Photography and the Representation of Space in W.G. Sebald and Monika Maron, s. 63].

27 Pisała: „fotografia to sztuka żałobna, schyłkowa [...]. Wszystkie fotografie mówią: «memento mori». Robiąc zdjęcia stykamy się ze śmiertelnością, kruchością, przemijalnością rzeczy i ludzi. Właśnie dlatego, że wybieramy jakąś chwilę, wykrawamy ją i zamrażamy, wszystkie zdjęcia stanowią świadectwo nieubłagalnego przemijania" [S. Sontag, O fotografii, przeł. S. Magala, Warszawa 1986, s. 19]. 
Jak twierdzi Gregory-Gider, Sebald umieszcza te fotografie zarówno jako obrazy świata materialnego, jak i reprezentacje odsyłające do znaczeń symbolicznych. Zdjęcia te są zastępczym portretem Selwyna i stanu jego ducha ${ }^{28}$.

Jednak - jak widać w przypadku przywołanego już tutaj zdjęcia dwojga osób z malowanym pejzażem alpejskim w tle, fotografii zamieszczonej w powieści Austerlitz - Sebald w sposób bardzo złożony traktuje ową moc multiplikacyjną samego medium. Na przykład w tekście Wyjechali pojawia się - przy opisie sceny oglądania zdjęć z podróży na Kretę dra Selwyna i jego przyjaciela - fotografia w następującym kontekście:

kilka razy widać było Edwarda z lornetką polową i puszką na okazy botaniczne albo dr Selwyna w szortach do kolan, z torbą przewieszoną przez ramię i siatką na motyle. Jedno ze zdjęć przypominało aż do najdrobniejszego szczegółu zrobioną w górach nad Gstaad fotografię Nabokova, którą parę dni wcześniej wyciąłem z jakiegoś szwajcarskiego pisma [W, s. 24].

Kłopot w tym, że to rzeczywiście powszechnie znane zdjęcie Nabokova zrobione mu przez syna Dmitrija w Alpach Szwajcarskich. Zdaniem Florence Feireisen i Daniela Pope'a, którzy analizują ten fragment jako przykład stosowanej przez Sebalda strategii, czytelniczy dylemat nie polega na tym, czy fotografia ta zostanie rozpoznana, czy nie. Rzecz w tym, że - zgodnie zresztą ze sformułowanymi wprost autorskimi intencjami wspomnianymi powyżej - odbiorca zmuszony jest porzucić linearną lekturę i skonfrontować tekst werbalny z obrazem: odnotować brak torby na ramieniu przedstawionej postaci, ocenić krajobraz w tle jako zbyt rozległy i górzysty, jak na własne wyobrażenie o pejzażach Krety - wreszcie - z pewną konsternacją stwierdzić, że ma przed sobą rzeczone zdjęcie Nabokova. Kolejny krok to oczywiście próba odpowiedzi na pytanie, jaką funkcję pełni tutaj ta fotografia, co nieuchronnie wydobywa kwestie metatekstowe - zmusza do rozważenia zasad konstrukcji całości tekstu ${ }^{29}$, zawieszając linearność lektury, „uprzestrzenniając" ją niejako. Efekt ten - pojawiający się zawsze przy tekstach wielo-

28 "Sebald positions this photograph somewhere between the material and the symbolic, meaning that it is both a fragment from the material world and a talismanic (even metaphysical) mediation upon it. In the absence of a conventional photograph of Selwyn in this half of the chapter, we are invited to read the above series of images as a kind of oblique biographical portrait, a collection of sites/sights whose content, tone, and arrangement bear a stamp of a now-extinguished life" [C. Gregory-Guider, Memorial Sights/Sites: Sebald, Photography and the Art of Autobiogeography in "The Emigrants", s. 522].

${ }_{29}$ F. Feireisen i D. Pope, True Fictions and Fictional Truths: the Enigmatic in Sebald's Use of Images in "the Emigrants", w: Searching for Sebald. Photography after W.G. Sebald, ed. by L. Patt with C. Dillholmer, Los Angeles 2007, s. 167-168. 
kodowych ${ }^{30}$ - zostaje $\mathrm{w}$ powieściach Sebalda, dzięki pokazanym wyżej zabiegom, wzmocniony. Takie studiowanie relacji między fotografią i tekstem eksponuje sam proces odbioru, zwracając uwagę szczególnie na kwestię tego, jak percepcja wizualna wpływa na lekturę tekstu zarówno werbalnego, jak i wizualnego ${ }^{31}$. Jak zauważa Horskotte, sam tekst staje się konstruktem czasowo-przestrzennym, w którym sekwencjonalność narracji zostaje zrównoważona możliwością pójścia rozmaitymi tropami sugerowanymi przez obrazy włączone w tekst werbalny. Dzieje się tak szczególnie wtedy, gdy zdjęcia pojawiają się $\mathrm{w}$ takich miejscach, że naruszają integralność poszczególnych fragmentów czy zdań ${ }^{32}$.

W przywołanych tu powieściach Sebalda przestrzeń - poza elementami wspólnymi - może pełnić rolę nie tyle specyficzną, co opartą na wzmocnieniu cechy obecnej również gdzie indziej. I tak w Austerlitzu pisarz wyeksponował labiryntowość, wyraźnie w jej Piranezjańskim wydaniu. W tekście zostaje to powiedziane nieomal expressis verbis w scenie, w której Austerlitz opisuje swoje przeżycia na opuszczonym londyńskim dworcu:

Zaledwie przez mgnienie oka mogłem dostrzec otwierającą się kolosalną przestrzeń, prowadzące $\mathrm{w}$ bezmierną dal rzędy filarów i kolumnady, sklepienia i wielokondygnacyjne konstrukcje łuków, kamienne schody, drewniane stopnie i drabiny, po których wzrok wędrował coraz dalej, przerzucone nad przepaściami kładki i pomosty, na których tłoczyły się drobne sylwetki, więźniowie, jak sobie pomyślałem - mówił Austerlitz - szukający wyjścia z tego lochu [...] pośród tej wizji uwięzienia i wyzwolenia dręczyło mnie pytanie, czy znajduję się wewnątrz jakiejś ruiny, czy też $\mathrm{w}$ dopiero powstającej budowli. W pewnym sensie wtedy, gdy na Liverpool Street nowy dworzec formalnie wyrastał z gruzów dawnego, jedno i drugie było prawdą [A, s. 167-168].

W powieści po wielokroć powracać będą dworce, owe nie-miejsca ${ }^{33}$, w których Austerlitz usiłuje skonfrontować się ze strzępkami wspomnień z prze-

30 Zob. G. Grochowski, Na styku kodów. O literackich użyciach znaków ikonicznych, „Teksty Dru-

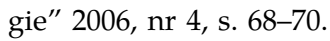

31 Zob. S. Horskotte, Photo-Text Topographies: Photography and the Representation of Space in W. G. Sebald and Monika Maron. Pisze ona: "Studying the spatial relationship of photography and text thus leads to a heightened awareness of reception processes, especially of how visual perception affects our reading of verbal as well as visual texts" [s. 74].

32 "Instead, the text itself becomes a kind of chrono-topography, in which the sequentiality of the narrative is balanced out by the different reading paths offered by the inserted images: these call for constant decisions regarding the order in which images and narrative are read-especially where the image breaks up the integrity of a paragraph, sentence, or word" [S. Horskotte, Photo-Text Topographies: Photography and the Representation of Space in W. G. Sebald and Monika Maron, s. 61].

33 Zob. M. Augé, Nie-Miejsca. Wprowadzenie do antropologii hipernowoczesności, przeł. R. Chymkowski, Warszawa 2010. 
szłości i odpowiedzieć sobie na pytanie o własną tożsamość, by ostatecznie dowiedzieć się, że jest ocalonym z Zagłady dzieckiem czeskich Żydów ${ }^{34}$. W jednym $\mathrm{z}$ wywiadów Sebald zwrócił uwagę na to, że:

Istniała bardzo, bardzo bliska identyfikacja pomiędzy żydowską i nieżydowską społecznością w Niemczech. A szczególnie pomiędzy populacją żydowską a krajem, topografią kraju, która wyrażała się w ich nazwiskach. Nazywali się Frankfurt lub Hamburger czy Wiener. Identyfikowali się z tymi miejscami ${ }^{35}$.

W tym kontekście nazwisko głównego bohatera powieści, odwołuje się nie tyle do miejsca słynnej bitwy z okresu wojen napoleońskich, co do nazwy paryskiego dworca, z którego - jak się Austerlitz dowiaduje - po wejściu Niemców opuszczał Paryż jego ojciec:

Wyobrażałem sobie - mówił Austerlitz - że go widzę, jak w chwili odjazdu wychyla się z okna przedziału, widziałem też, jak nad ciężko ruszającą z miejsca lokomotywą unoszą się białe obłoki pary. Na wpół przytomny błądziłem po dworcu, przez labirynt podziemnych korytarzy, kładkami dla pieszych, w górę i w dół. Ten dworzec - mówił Austerlitz - zawsze był dla mnie najbardziej zagadkowy ze wszystkich paryskich dworców [A, s. 352].

Nic dziwnego zatem, że ostatnie dzieło Sebalda interpretowano jako realizację motywu katabazy ${ }^{36}$, idąc za wyrażoną wprost $\mathrm{w}$ tekście sugestią, że labirynt przy Liverpool Street jest wejściem do krainy zmarłych. Taki kontekst wyraźnie ma też Sebaldowski - jak sam to nazywał - „kompulsywny topografizm" ${ }^{37}$ - który w Austerlitzu przybiera formę rozmaicie realizowanej labiryntowości, pojawiającej się również w postaci obrazów planów twierdz czy dworców właśnie.

W Austerlitzu też najlepiej widać wyraźne uprzywilejowanie przestrzeni w światach kreowanych przez Sebalda. Bohater zwierza się tam narratorowi:

34 Owa labiryntowość, jak sugeruje sam bohater, realizuje się również jako metafora kłopotów z wyrażeniem własnych doświadczeń. Austerlitz mówi: „Jeśli porównać język do starego miasta, z plątaniną uliczek i placów, z dzielnicami sięgającymi daleko w głąb czasu, z kwartałami wyburzonymi, zmodernizowanymi i nowo zbudowanymi, i z coraz dalej rozprzestrzeniającymi się peryferiami, to ja sam przypominałem człowieka, który wskutek długiej nieobecności nie orientuje się już w tej aglomeracji, nie wie, do czego służy przystanek. Czym jest podwórze, skrzyżowanie, bulwar albo most" [s. 154].

35 E. Wachtel, Łowca duchów, s. 35.

36 Zob. A. Itkin, "Eine Art Eingang zur Unterwelt”: Katabasis in "Austerlitz", in The Undiscover'd Country. W. G. Sebald and the Poetics of Travel, ed. by M. Zisselsberger, Rochester, New York 2013.

37 Zob. W.G. Sebald, Próba restytucji, „Zeszyty Literackie” 2012, nr 2, s. 31. 
Nie sądzę - powiedział Austerlitz - byśmy rozumieli prawa, które rządzą powrotem przeszłości, ale coraz mocniej przekonany jestem, że czasu w ogóle nie ma, są tylko różne, zazębiające się ze sobą wedle wyższych zasad stereometrii przestrzenie, pomiędzy którymi żywi i umarli mogą się przemieszczać, jeśli chcą, i im dłużej się nad tym zastanawiam, tym bardziej mi się wydaje, że my, żywi, w oczach umarłych jesteśmy nierealnymi istotami, widzialnymi tylko czasem, w określonych warunkach atmosferycznych. Odkąd pamiętam mówił Austerlitz - zawsze nawiedzało mnie poczucie, że nie mam swego miejsca $\mathrm{w}$ rzeczywistości, że wcale nie istnieję, i poczucie to nigdy nie było tak silne, jak tego wieczoru na Szporkovej, pod przeszywającym spojrzeniem pazia Królowej Róż [A, s. 228-229] ${ }^{38}$.

Ważność owej, jakby wyssanej z czasu, przestrzeni objawia się w powieściach pisarza też w inny sposób - dzięki kontaktowi z Karlowymi Varami, z rozlicznymi dworcami, do Austerlitza powracają cienie wspomnień. Jeden z bohaterów Wyjechali, Faber, powie zaś: „Manchester zawładnął mną bez reszty" [W, s. 216]. Postacie Sebalda więc są niejako nawiedzane przez miejsca, których dotkliwie doświadczają.

To tym ciekawsze, że przestrzeń u Sebalda - szczególnie w Pierścieniach Saturna - jest przestrzenią zmediatyzowaną: pokazywaną w ikonicznych reprezentacjach, ale przede wszystkim już przez kogoś odwiedzoną, opisaną, utekstowioną. Tekstami Sebalda zdaje się też rządzić „kompulsywna deskrypcja", żeby sparafrazować przywoływane już autorozpoznanie pisarza. $W$ każdym z jego utworów znajdziemy szczegółowe opisy wymarłych miasteczek, bezludnych krajobrazów, dawnych hoteli popadających $\mathrm{w}$ ruinę, cmentarzy i parków. W Pierścieniach Saturna na przykład czytamy:

The night of time - zauważa Thomas Browne w napisanym $\mathrm{w} 1658$ roku traktacie The Garden of Cyrus - far surpasseth the day and who knows when was the Aequinox? Takie myśli mnie również tłukły się po głowie, gdy od mostu nad Blyth wędrowałem wzdłuż nieczynnych torów kolejowych, a potem zszedłem niżej, na równinę, ciągnącą się od Walberswick na południe aż do Dunwich, miejscowości, która dziś składała się z niewielu domów. Okolica jest tak pusta i bezludna, że ktoś wysadzony tu na ląd nie umiałby powiedzieć, czy znajduje

38 Komentując ten obraz, Katarzyna Bojarska pisze: „Martwi i żywi zamieszkują ten sam bezczasowy świat. To wcale nie umarli jawią się jako duchy żywym, ale na odwrót. Nie zmienią tego nawet zdjęcia, na których wszyscy i tak nie-żyjemy. Nie sposób zatem oczekiwać od nich, że przywrócą porządek i oddzielą to, co było, od tego, co jest, zawiązując między tymi dwoma czasami nić porozumienia i znaczenia, nić życia" [Widmowość a możliwość widzenia (utraty). Fotografia przeciw referencjalności historii, http:// opposite.uni.wroc.pl/2012/bojarska.htm [dostęp 1.06.2015]. 
się na wybrzeżu Morza Północnego, czy nad Morzem Kaspijskim albo w zatoce Liandong. Mając po prawej stronie falujące trzciny, po lewej szarą plażę, ruszyłem ku Dunwich, które wydawało się tak dalekie, że nieosiągalne ${ }^{39}$.

Świat Sebalda - co jednak trzeba tu powiedzieć, mimo niebezpieczeństwa popadnięcia w banał i oczywistość - to miejsce po katastrofie, kolekcja emblematów dawnej kultury mieszczańskiej, traktowanych z czułością i podejrzliwością zarazem, bo przynależą do porządku, który wydał z siebie Zagładę. Z przymusu opowiadania o śladach zaledwie, resztkach i znakach tego, co nieodwracalnie przeminęło, zdaje się brać Sebaldowska - widoczna w choćby w graficznych projektach okładek - obsesja odbić, którą najdobitniej formułuje Austerlitz:

powiedziałem coś o niepojętej zagadce zwierciadlanych odbić, na co Austerlitz odparł, że on też często po zapadnięciu nocy siedzi w tym pokoju i wpatruje się $\mathrm{w}$ odbity $\mathrm{w}$ ciemności na dworze, na pozór nieruchomy świetlisty punkt, i że nieuchronnie przypomina mu się wtedy, jak przed laty, na wystawie Rembrandta w Rijksmuseum w Amsterdamie, gdzie nie chciało mu się zatrzymać przed żadnym z setki razy reprodukowanych arcydzieł wielkiego formatu, za to długo stał przed małym, mierzącym jakieś dwadzieścia na trzydzieści centymetrów i, o ile pamięta, pochodzącym ze zbiorów w Dublinie obrazkiem, przedstawiającym, według podpisu, scenę ucieczki do Egiptu, na którym jednak nie mógł rozpoznać ani świętej pary, ani Dzieciątka Jezus, ani zwierzęcia jucznego, a tylko pośrodku lśniąco czarnego werniksu ciemności, maleńką, w moich oczach - mówił Austerlitz - do dziś niezgasłą plamkę ognia [A, s. 149].

Sebald w tekście Austerlitza sam podejmie grę ujawniającą pozorność zwierciadlanych odbić. W opowieść bohatera o przechadzce po terezińskich ulicach, gdy ten ogląda $\mathrm{w}$ niewielkiej gablocie rozmaite bibeloty i dostrzega w szybie "słabo i niewyraźnie" swoje własne odbicie, pisarz włącza zdjęcie wystawy ze stojącą nań opisywaną przez Austerlitza figurką z kości słoniowej i ledwie widocznym w oknie wystawowym zarysem sylwetki. Jednak uważny czytelnik rozpozna w tym odbiciu twarz samego pisarza [s. 241]. Sebald na wielu poziomach swoich tekstów stara się bowiem podważyć proste relacje między obiektem a jego reprezentacją, gra kategorią autentyczności, świadectwa, dokumentu. Obsesyjnie opisywane, "cytowane” w ikonicznej postaci przedmioty, miejsca, nawet ludzie, zdają się u Sebalda zaledwie jakimś poblaskiem rzeczywistych obiektów.

39 W.G. Sebald, Pierścienie Saturna, przeł. M. Łukasiewicz, Warszawa 2009, s. 177. Kolejne cytaty z powieści lokalizuję w tekście głównym, sygnując je skrótem PS. 
Cartsten Strathausen o dziełach Sebalda pisze:

podobnie jak pierwsza fotografia okna w Pierścieniach Saturna, wszystkie inne fotografie Sebalda służą jako bramy ucieczki z labiryntowej topografii jego tekstualnych pejzaży. Włączenie fotografii pozwala czytelnikowi podróżować daleko poza dyskursywne uniwersum tekstu, dostarczając tym samym głównego wyjścia z hermeneutycznego więzienia, wyjścia tak rozpaczliwie poszukiwanego (ale nieosiągalnego) przez diegetycznych bohaterów. [...] Fotografie Sebalda dają możliwość czytelnikom - i wzywają ich - by podjęli własną podróż, która jest wysoce osobista, nieprzewidywalna i bezpośrednia, a tym samym wytycza nową ścieżkę przez nieskończoną przestrzeń życia ${ }^{40}$.

Przypomnijmy zatem ten fragment powieści: po przybyciu do szpitala narratora poraża wizja, „że przewędrowane poprzedniego lata w Suffolk rozległe obszary zbiegły się ostatecznie $\mathrm{w}$ jeden ślepy $\mathrm{i}$ głuchy punkt [...] bezbarwnego kawałka nieba w ramie okna [PS, s. 8]. Gdy wreszcie udaje mu się przez nie wyjrzeć, doznaje Kafkowskiego poczucia obcości:

nie mogłem sobie wyobrazić, by tam w dole, wśród bezładnie zazębiających się murów, coś się jeszcze poruszało, i byłem przekonany, że spoglądam z wysokiej skały na kamienne morze albo żwirowisko, z którego niczym kolosalne głazy narzutowe sterczą posępne bloki wielokondygnacyjnych parkingów [PS, s. 9].

Otóż nie jestem przekonana, czy owe Sebaldowskie okna oferują jakieś widoki na cokolwiek poza intradiegetyczną przestrzenią. Wbrew pozorom czyli wbrew fotografiom - ludzie, krajobrazy realia nie mają tu innej egzystencji poza intradiegetyczną. Zatem przestrzeń w utworach Sebalda jest utekstowiona w dużo większym stopniu, niż mogłoby się wydawać przy uwzględnieniu uruchomionych $w$ nich konwencji: quasi-reportażu, quasi-biografii, ich genologicznej afiliacji.

Być może jako jego czytelnicy jesteśmy - wraz Sebaldem-wędrowcem i z jego bohaterami - zamknięci w Piranezjańskich wnętrzach, spiętrzających regały z książkami i dokumentami, przemierzamy pustkowia (w środku Anglii), wymarłe miasteczka i w pełni sezonu bywamy jedynymi gośćmi podupadłych pensjonatów. Pytanie brzmi - czemu odwiedzamy je tak chętnie?

${ }^{40}$ C. Strathausen, Wędrowanie donikąd. Sebalda podróże po rozwidlających się ścieżkach, s. 50. 
Remarks on Constructing Space in W.G. Sebald's Fiction Summary

The article reflects upon the way in which writings by W.G. Sebald mediate between the constructing of space and hybridity. Specifically, the function of photography within the narration is analyzed here. In conclusion, photographs, despite their strong referential charge, do not in any way diminish the undoubted textualization of space in Sebald's works.

Keywords: literary space, hybridity, textualization, W.G. Sebald 